\title{
Metastasizing ependymoma of the cauda equina
}

\author{
D. G. D. WIGHT ${ }^{1}$, K. J. HOLLEY ${ }^{2}$, AND J. A. H. FINBOW \\ From the Department of Histopathology, St George's Hospital Medical School, London, and \\ Hillingdon Hospital, Uxbridge, Middlesex
}

SYNOPSIS A case of metastasizing ependymoma is described, only the second in the British literature. The tumour, which arose in the cauda equina, spread to humerus and pleura over a period of 32 years. It is postulated that, in common with most of the previously reported cases, dissemination was a direct consequence of either surgical intervention or radiotherapy since neither the primary tumour nor its metastases shows any of the conventional morphological criteria of malignancy. The literature of similar cases is briefly reviewed.

It is only within the last 20 years that gliomas with distant metastases have been described, and they remain exceedingly rare. The western literature now contains 19 reported cases of ependymomas with metastases (tables I and II), the first in 1952 by Mastragostino. The present case is only the second to be described in the British literature, and is the fifth metastasizing intraspinal ependymoma to be reported.

\section{Case Report}

The patient, then a 20 -year-old male, first complained of pain in the lumbar region in 1932. He was investigated in various hospitals but no cause for his symptoms was found. In 1940 the pain became more severe and he developed an early paraparesis. Investigation demonstrated a lesion in the lumbar spinal cord and a laminectomy of segments D11 to L3 was performed. The surgeon found a large vascular tumour spreading from the lower end of the spinal cord to the sacrum. Most of the tumour, considered pathologically to be a cellular meningioma, was removed at that time and the patient received postoperative radiotherapy. He made a complete recovery and was able to resume his occupation.

He remained symptom free for 15 years until 1955, when, at the age of 43 , he presented with difficulty with micturition and defaecation and weakness in the

${ }^{1}$ Present address : Department of Pathology, Addenbrooke's Hospital, Cambridge

2Present address: Department of Pathology, Warwick General Hospital, Lakin Road, Warwick.

Received for publication 21 August 1973. right leg. Investigation again indicated a lesion in the lumbar spinal canal. On 21 January 1955 the region was explored by the same surgeon, and he again found an extensive bluish-red, vascular tumour, extending from D11 to L4. He felt that the local appearances were those of an ependymoma and was unable to remove all the tumour because of difficulty in distinguishing tumour from cord and spinal nerves. Postoperatively the patient received another course of radiotherapy and made a good recovery, apart from persisting loss of sphincter control. The histopathologist reported the recurrence as a vascular meningioma similar to the original tumour. He remained symptomless for another four years, until in 1959 there was a recurrence of lumbar pain, followed by development of weakness in the left leg, which progressed over a period of 14 months to paraplegia and urinary incontinence. Over the same period he developed complete sensory loss below the level of D7. Further surgery was considered inadvisable and radiotherapy was contraindicated because of existing radionecrosis of the skin of the sacral region. He had to give up his work as a commercial traveller in 1960 and he remained confined to a wheelchair, but his general health continued to be fairly good, apart from recurrent urinary infections.

In February 1969 he experienced a sudden, sharp pain in the right arm while pulling himself up in bed. He was readmitted to another hospital where radiographs of the humerus revealed an osteolytic lesion in the lower third with a pathological fracture through its centre. This lesion was biopsied and reported as a cellular meningioma. Treatment was by immobilization in a plaster cast. The fracture 


\begin{tabular}{|c|c|c|c|c|c|c|c|c|c|}
\hline Author & Date & $\begin{array}{l}\text { Age at } \\
\text { Presentation }\end{array}$ & $\operatorname{Sex}$ & Site & $\begin{array}{l}\text { Histological } \\
\text { Type }\end{array}$ & Surgery ${ }^{1}$ & Radiotherapy & $\begin{array}{l}\text { Site of } \\
\text { Metastases }\end{array}$ & Survival \\
\hline Mastragostino & 1952 & 44 & $\mathbf{M}$ & $\begin{array}{l}\mathrm{R} \text { temporo- } \\
\text { occipital region }\end{array}$ & $\begin{array}{l}\text { Papillary } \\
\text { ependymoma }\end{array}$ & - & - & $\begin{array}{l}\mathbf{R} \text { lung } \\
\text { subpleural }\end{array}$ & 6 years \\
\hline Maass & 1954 & 27 & $\mathbf{M}$ & L occipital lobe & Ependymoblastoma & $+(3)$ & + & $\begin{array}{l}\text { Cervical } \\
\text { lymph node }\end{array}$ & 2 years \\
\hline $\begin{array}{l}\text { Sherbianuk } \\
\text { and Shnitka }\end{array}$ & 1956 & 16 & $\mathrm{~F}$ & $\begin{array}{l}\text { L parietal } \\
\text { region }\end{array}$ & Ependymoma & $+(4)$ & + & Pleura & 13 years \\
\hline Breslich & 1957 & 13 & $\mathbf{M}$ & R occipital lobe & $\begin{array}{l}\text { Ependymoma } \\
\text { grade III }\end{array}$ & $+(2)$ & + & $\begin{array}{l}\text { R lung, } \\
\text { pleura, } \\
\text { hilar nodes }\end{array}$ & 2 years \\
\hline Perry & 1957 & 39 & $\mathbf{M}$ & L parietal lobe & Ependymoma & $+(2)$ & + & $\begin{array}{l}\text { Liver, femur, } \\
\text { spinal cord }\end{array}$ & 6 years \\
\hline $\begin{array}{l}\text { Wen and } \\
\text { Barrows }\end{array}$ & 1957 & 9 & $\mathbf{M}$ & Frontal lobe & $\begin{array}{l}\text { Cellular } \\
\text { ependymoma }\end{array}$ & $+(2)$ & + & $\begin{array}{l}\text { Lungs, } \\
\text { hilar nodes, } \\
\text { axillary nodes }\end{array}$ & 1 year \\
\hline Perrin & 1958 & 3 & $\mathbf{M}$ & $\mathbf{R}$ cerebellum & Ependymoblastoma & $+(2)$ & + & $\begin{array}{l}\text { R lung, } \\
\text { mediastinum }\end{array}$ & 1 year \\
\hline $\begin{array}{l}\text { Glasauer and } \\
\text { Yuan }\end{array}$ & 1963 & $2 \frac{1}{2}$ & $\mathbf{M}$ & L occipital lobe & $\begin{array}{l}\text { Ependymoblastoma } \\
\text { grade IV }\end{array}$ & $+(3)$ & + & $\begin{array}{l}\text { Lungs, } \\
\text { hilar lymph } \\
\text { nodes }\end{array}$ & 1 year \\
\hline $\begin{array}{l}\text { MacMahon } \\
\text { and Urista }\end{array}$ & 1964 & 3 & $\mathbf{M}$ & $\begin{array}{l}\text { L lateral } \\
\text { ventricle }\end{array}$ & $\begin{array}{l}\text { Malignant } \\
\text { ependymoma }\end{array}$ & $+(2)$ & - & $\begin{array}{l}\text { Lungs, } \\
\text { mediastinal } \\
\text { lymph nodes } \\
\text { Pleura }\end{array}$ & 1 year \\
\hline $\begin{array}{l}\text { Hesselvik and } \\
\text { Tygstrup }\end{array}$ & 1965 & 2 & $\mathbf{M}$ & $\mathbf{R}$ parietal lobe & Ependymoblastoma & $+(3)$ & + & Pleura & 1 year \\
\hline \multirow[t]{2}{*}{$\begin{array}{l}\text { Fragoyannis } \\
\text { and Yalcin }\end{array}$} & $1966 \mathrm{i}$ & 22 & $\mathbf{M}$ & R occipital lobe & $\begin{array}{l}\text { Ependymoma } \\
\text { grade III }\end{array}$ & $+(2)$ & + & $\begin{array}{l}\text { Cervical } \\
\text { lymph node, } \\
\text { vertebrae }\end{array}$ & 1 year \\
\hline & ii & 7 & $\mathbf{F}$ & $\begin{array}{l}R \text { fourth } \\
\text { ventricle }\end{array}$ & $\begin{array}{l}\text { Ependymoma } \\
\text { grade II }\end{array}$ & $+(4)$ & - & $\begin{array}{l}\text { Skull bones, } \\
\mathbf{R} \text { femur }\end{array}$ & 1 year \\
\hline $\begin{array}{l}\text { Wentworth } \\
\text { and Birdsell }\end{array}$ & 1966 & $2 \frac{1}{2}$ & $\mathbf{M}$ & $\begin{array}{l}\text { L parieto- } \\
\text { occipital region }\end{array}$ & $\begin{array}{l}\text { Ependymoma } \\
\text { grade IV }\end{array}$ & $+(3)$ & - & $\begin{array}{l}\text { Mediastinum, } \\
\text { L lung }\end{array}$ & 1 year \\
\hline $\begin{array}{l}\text { Robinson and } \\
\text { Sharkey }\end{array}$ & 1967 & 14 & $\mathbf{M}$ & Third ventricle & $\begin{array}{l}\text { Ependymoma } \\
\text { grade IV }\end{array}$ & $+(1)$ & + & $\begin{array}{l}\text { Lung, } \\
\text { pleura }\end{array}$ & 2 years \\
\hline $\begin{array}{l}\text { Højgaard and } \\
\text { Johansen }\end{array}$ & 1970 & 13 & $\mathbf{M}$ & Fourth ventricle & $\begin{array}{l}\text { Malignant } \\
\text { ependymoma }\end{array}$ & $+(2)$ & + & $\begin{array}{l}\text { Subcutis, } \\
\text { lung, pleura } \\
\text { liver, kidney }\end{array}$ & 9 month \\
\hline
\end{tabular}

\section{Table I Intracranial ependymomas}

${ }^{2}$ The figure in brackets indicates the number of surgical operations

\begin{tabular}{|c|c|c|c|c|c|c|c|c|c|}
\hline Author & Date & $\begin{array}{l}\text { Age at } \\
\text { Presentation }\end{array}$ & Sex & Site & $\begin{array}{l}\text { Histological } \\
\text { Type }\end{array}$ & Surgery ${ }^{1}$ & Radiotherapy & $\begin{array}{l}\text { Sites of } \\
\text { Metastases }\end{array}$ & Survival \\
\hline Weiss & 1955 & 22 & $\mathbf{M}$ & Cauda equina & $\begin{array}{l}\text { Myxopapillary } \\
\text { ependymoma }\end{array}$ & $+(5)$ & $+(2)$ & $\begin{array}{l}\text { Retroperitoneum, } \\
\text { liver, } \\
\text { pleura, } \\
\text { lung, } \\
\text { hilar lymph node, } \\
\text { chest wall }\end{array}$ & 10 years \\
\hline Sharma & 1956 & 29 & $\mathbf{M}$ & Cauda equina & Ependymoma & $+(3)$ & + & $\begin{array}{l}\text { Liver, lungs, } \\
\text { pleura, } \\
\text { mediastinum, } \\
\text { chest wall }\end{array}$ & 4 years \\
\hline $\begin{array}{l}\text { Patterson } \\
\text { et al }\end{array}$ & 1961 & 28 & $\mathbf{F}$ & Cauda equina & $\begin{array}{l}\text { Myxopapillary } \\
\text { ependymoma }\end{array}$ & $+(3)$ & $+(2)$ & $\begin{array}{l}\text { Vertebrae, } \\
\text { superior and } \\
\text { anterior } \\
\text { mediastinum, } \\
\text { pleura, lung, } \\
\text { hilar lymph nodes }\end{array}$ & 17 years \\
\hline $\begin{array}{l}\text { Rubinstein } \\
\text { and Logan }\end{array}$ & 1970 & 17 & F & Cauda equina & Ependymoma & $+(3)$ & $+(5)$ & $\begin{array}{l}\text { Fourth ventricle } \\
\text { lung, pleura, } \\
\text { lymph node }\end{array}$ & 29 years \\
\hline Wight et al & 1971 & 28 & $\mathbf{M}$ & Cauda equina & Ependymoma & $+(2)$ & $+(2)$ & $\begin{array}{l}\text { Humerus, } \\
\text { pleura }\end{array}$ & 31 years \\
\hline
\end{tabular}

\section{Table II Spinal ependymomas}

${ }^{1}$ The figure in brackets indicates the number of surgical operations or courses of radiotherapy 
healed but he sustained a second fracture through the same site in January 1970 at which time the patient was referred to St George's Hospital. The osteolytic lesion was now treated by Cobalt 60 therapy. Chest radiographs taken at this time showed a rounded opacity at the left apex, with destruction of the third rib and pleural reflection off its upper margin. Review of earlier chest films showed that this lesion had been present at the time of the first pathological fracture of the humerus, 11 months earlier. The mass was thought to lie in the parietal pleura or chest wall. This impression was confirmed at operation when portions of a soft dark tumour were removed for histopathological examination. The pleural lesion was treated postoperatively with Cobalt 60.

When seen in April 1971 the pathological fracture in the humerus had completely healed, and growth of the pleural lesion had been arrested. His general condition, however, gradually deteriorated and he died of renal failure in December 1972 at the age of 60, 40 years after first presentation. Postmortem examination was carried out on the day of his death.

\section{Postmortem Findings}

He was a prematurely aged man with oedema and shortening of the right leg. The acetabulum on this side was exposed through a large area of ulceration involving the sacrum and the right side of the pelvis. A suprapubic cystostomy had been performed.

Bulging into the pleural cavity of the left side and involving the second, third, and fourth ribs of the midaxillary line was an oval, soft tumour covered by pleura and having a grey, blotchy surface $7.0 \times$ $3.0 \times 10.0 \mathrm{~cm}$ (fig 1). A similar lesion involving the seventh, eighth, and ninth ribs in the posterior axillary line $11.0 \times 7.0 \times 4.0 \mathrm{~cm}$ was present in the right pleural cavity. Slicing of both of these lesions showed a trabeculated, white cut surface with small translucent areas and minute cyst formation. There were also several other small sessile nodules scattered over both parietal pleurae.

The peritoneum and retroperitoneal tissues of the pelvis were infiltrated by firm white tumour which surrounded the vessels and the ureters; the latter were dilated. Tumour also extended into the retroperitoneal space just above the brim of the pelvis on the right side and within the paracolic gutter of the left side to the lower pole of the kidney. The lower paraaortic lymph nodes were included in this tumour. Each kidney was small (weight $100 \mathrm{~g}$ ) and showed marked cortical scarring and hydronephorisis. No vascular permeation was noted.

A longitudinal wedge through the lower vertebrae and sacrum showed collapse of L5 with partial replacement by white tumour. The cauda equina was replaced by a firm white tube of tumour limited by the dura. The pathological fracture of the humerus was well healed.

\section{Histopathology}

The tumour was first biopsied in 1940 and the pathologist's report concluded that the tumour was a cellular meningioma, a diagnosis that was under-

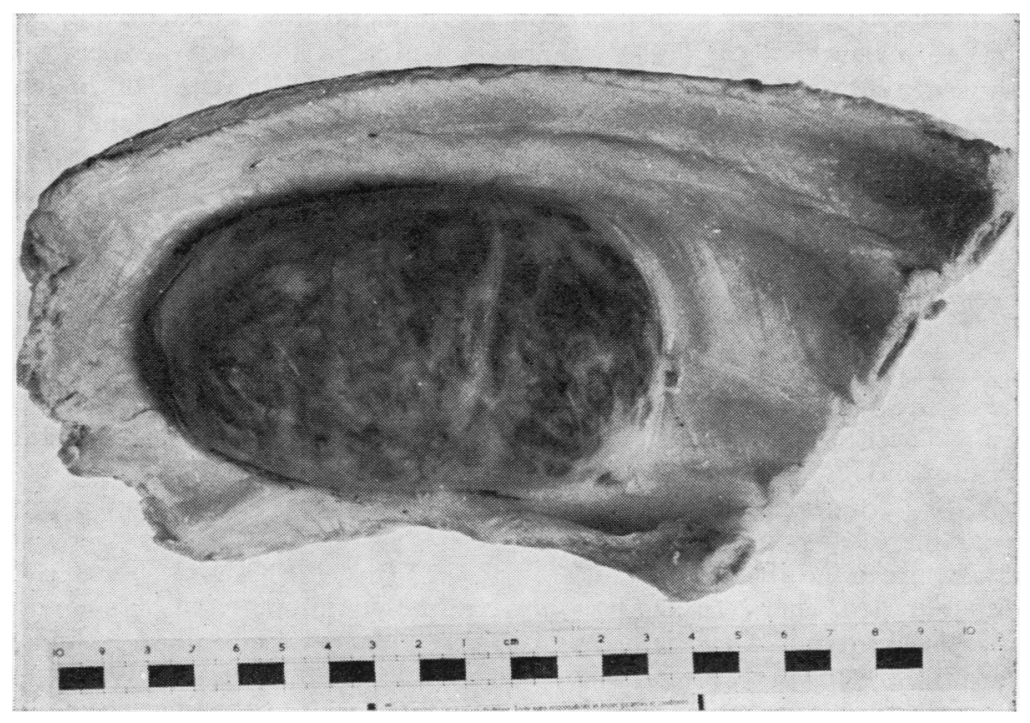

Fig 1 Secondary deposit in the left parietal pleura. 


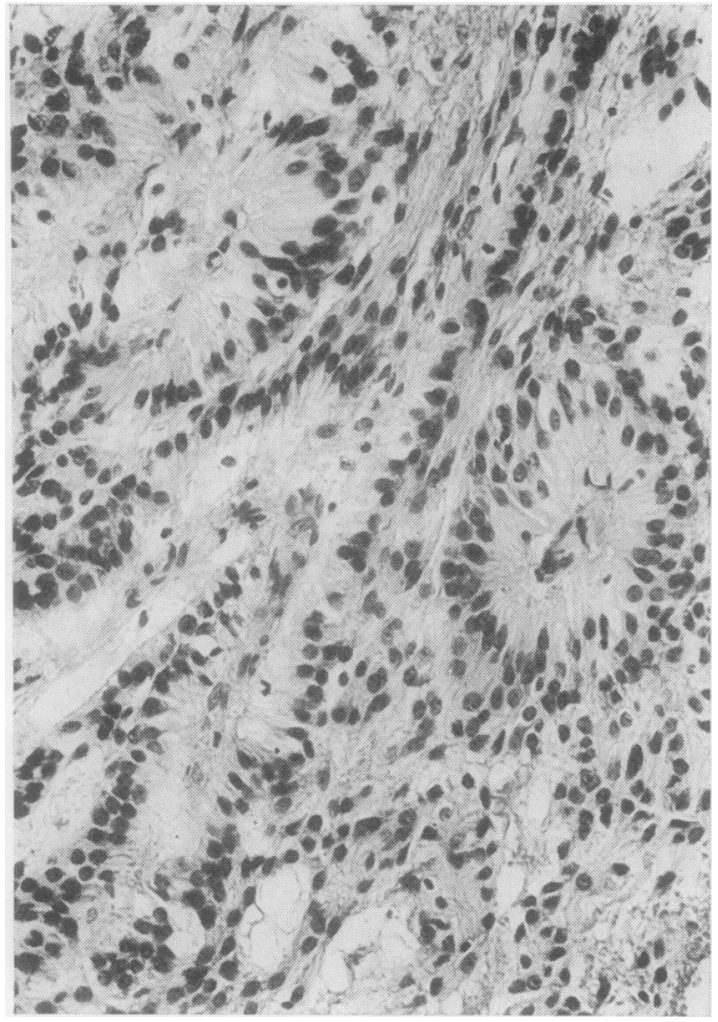

Fig 2 Typical cellular ependymoma with pseudorosettes showing long tapering processes attached to the central blood vessels. Biopsy from recurrence of cauda equina lesion taken in 1955. $\mathrm{H} \& \mathrm{E} \times 216$

standably perpetuated on subsequent occasions. Unfortunately we have been unable to review these sections since all the material was destroyed during an air raid in 1942. Fortunately, the sections from the 1955 biopsy are still available. These show a cellular and very vascular tumour. It consists of uniform cells with an ill defined cellular border and in some areas there is a tendency for these to be arranged around small blood vessels in the form of pseudorosettes. In these areas the blood vessels are surrounded by a halo formed of the tapering processes of the neoplastic cells. Special stains did not show any foot plates on the vessel wall. There is little evidence of cellular pleomorphism and mitotic figures are scanty. There are also a few true ependymal spaces. Although we were unable to demonstrate blepharoplasts the appearances are none the less typical of a fairly well differentiated ependymoma (grade II according to the criteria of Kernohan and Sayre, 1952). Figure 2 shows a typical field from this biopsy.

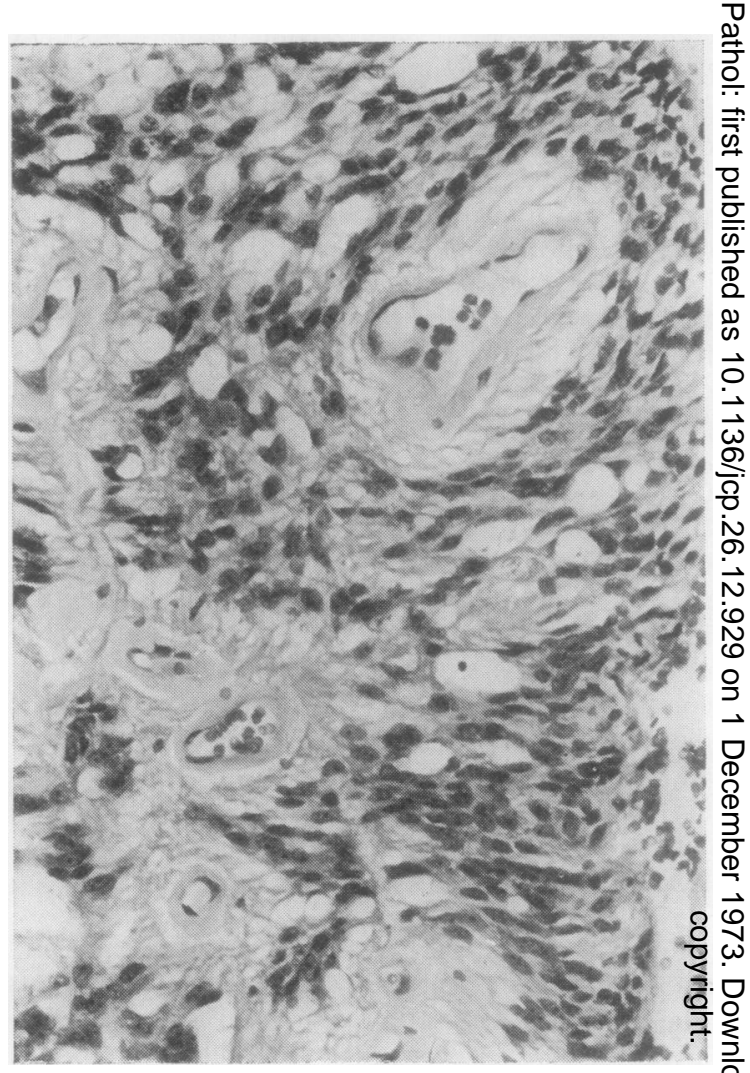

Fig 3 Transition between the appearances in figures 1 and 3. The vessels show hyaline thickening of their walls but no true papilla formation. Lesion in humerus in 1970. $H \& E \times 216$

Biopsy from the humeral lesion in 1970 shows a similar tumour. However, in addition there are well developed papillae with central cores of hyaline? acellular fibrous tissue, most of which contain a cluster of small blood vessels. This 'appearance is now more typical of a myxopapillary ependymoma, 웅 a tumour which is found almost exclusively in the cauda equina region. The final biopsy, from the pleural deposit, shows an essentially similar picture $\frac{?}{0}$ (figs 3 and 4). Representative sections from the postmortem material are identical (fig 5). Thus neither $N$ the primary tumour not its metastases show any of $N$ the conventional morphological criteria of malig- N nancy.

\section{Discussion}

Ependymomas are the commonest tumours of glial $\stackrel{\oplus}{+}$ origin found in the spinal cord and filum terminale $\frac{T}{0}$ (Kernohan and Sayre, 1952), and in this site are $\frac{\vec{D}}{\mathrm{D}}$ frequently of papillary or myxopapillary type. In $\frac{\mathcal{D}}{\mathbb{D}}$ 


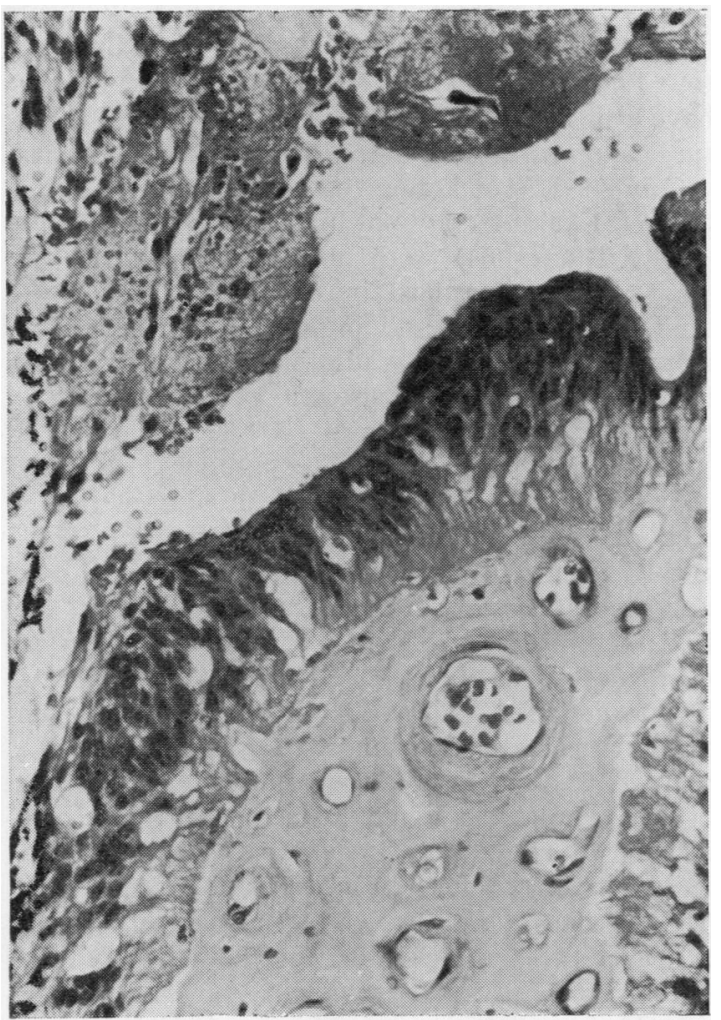

Fig 4 Papilla with hyaline stromal core containing blood vessels and partly covered by epithelial ependymal cells. Pleural deposit 1970. $\mathrm{H} \& \mathrm{E} \times 216$

their large series of 979 intraspinal neoplasms these authors found that $22.5 \%$ were gliomas and of these more than $60 \%$ were ependymomas. It is difficult to obtain an estimate of the true frequency of these tumours since the data from neurosurgical units tend to be heavily biased by selection factors. However, from the figures quoted by Poser (1956) their incidence in routine necropsies lies in the range $0.01-0.06 \%$.

Ependymomas are notably benign in terms of their degree of circumscription and cytological features. However, they may be locally invasive, particularly those arising in the posterior fossa in infancy (Russell and Rubinstein, 1971) and occasionally highly malignant with widespread metastases. Metastases by means of the cerebrospinal fluid pathway, despite the intimate relation of so many ependymomas to the ventricular system, are rare. Svien, Mabon, Kernohan, and Craig (1953) found subarachnoid implantation in six out of 19 cases. Spread of ependymomas in continuity to the extracranial and extravertebral soft tissue was first described by

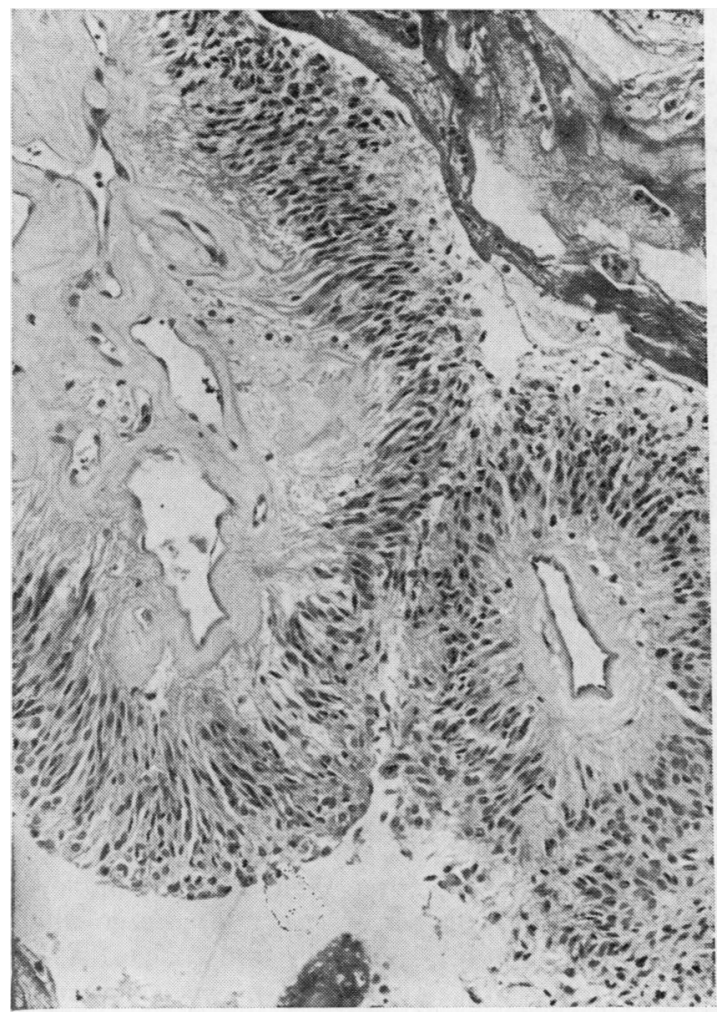

Fig 5 Papillae with well developed hyaline stromal cores containing blood vessels. Cauda equina, at necropsy 1972. $H$ \& $E \times 84$

Feigin and Volk (1951) and subsequently by other authors (Heath, 1963; Anderson, 1966; Tenekoon, 1968). In all these cases local infiltration was a postoperative event, some cases also having been treated with radiotherapy.

The first acceptable case of an ependymoma with distant metastases was reported in the Italian literature by Mastragostino (1952). This patient was a male, 44 years old, who had a temporo-occipital tumour with lung and subpleural metastases at necropsy. Weiss (1955) described a case of metastasizing ependymoma of the cauda equina. This patient was a 22-year-old male with a myxopapillary tumour of the cauda equina who, at necropsy 10 years after presentation, had widespread retroperitoneal, liver, pleural, lung, hilar node, and chest wall metastases. This was the first intraspinal ependymoma with metastases to be described and there have been only three subsequent cases. Sharma's case (1956) was very similar although total survival was only four weeks. In 1961 Patterson, Campbell, and Parsons described another myxopapillary ependy- 
moma in a 28-year-old female. This patient survived 17 years after diagnosis and at necropsy there was extensive abdominal and thoracic spread. The third case (Rubinstein and Logan, 1970) was a 17-year-old female who presented with a cauda equina lesion followed, six years later, by a similar tumour in the fourth ventricle which was thought to be a rostral metastasis. She finally died 29 years after presentation with extension of the primary tumour into the pelvis where it had surrounded the ureters, and lymph node, lung, and pleural metastases. The relevant features of previously published cases are summarized in tables I and II.

It is of interest that there is very poor correlation between the histological type of the ependymoma and the tendency to metastasize. Seven of the 19 cases (Maass, 1954; Perrin, 1958; Glasauer and Yuan, 1963; Hesselvik and Tygstrup, 1965; Wentworth and Birdsell, 1966; Robinson and Sharkey, 1967; Højgaard and Johansen, 1970) are of the form showing most cytological atypia, ependymoblastoma, or ependymoma grade IV. Two cases belong to grade III (Breslich, 1957; Fragoyannis and Yalcin, 1966), and the remainder are well differentiated (grade I or II) (Mastragostino, 1952; Weiss, 1955; Sherbaniuk, and Shnitka, 1956; Sharma, 1956; Wen and Barrows, 1957; Perry, 1957; Patterson et al, 1961 ; Fragoyannis and Yalcin, 1966; Rubinstein and Logan, 1970; Wight, Holley, and Finbow, 1973). This is in marked contrast to the behaviour of these tumours within the nervous system where spread is closely correlated with rapidity of growth and pleomorphism (Kernohan and Fletcher-Kernohan, 1935). In the present case it is also notable that there was no evidence that the metastatic tumour was any less well differentiated than the primary sacral lesion, and indeed the pleural deposits have all the characteristics of benign tumours. Of the spinal tumours, only in that described by Rubinstein and Logan (1970) was there any evidence of cytological anaplasia and this the authors attributed to radiotherapy since it was confined to the irradiated areas.

It had been held for many years that gliomas were virtually incapable of remote metastases and it is generally assumed that, as stressed by MacMahon and Urista (1964), this is because glial cells either do not or cannot invade the lumina of blood vessels. The work of Zimmerman $(1955,1957)$ appears to support this thesis. He showed that homogenates from experimentally induced gliomas in mice, when injected directly into the blood stream of mice, commonly metastasize to such organs as the lungs, liver, spleen, and kidneys. These experiments show that glial cell tumours in mice are capable of growing in other parts of the body, although they do not do so spontaneously, and give little support to the alternative hypothesis that tumour cells may invade the blood stream but find a hostile environment and $\mathrm{P}$. thus fail to implant. Russell and Rubinstein (1971) have little doubt that remote metastases are a purely? surgical hazard, and indeed in all but one (Mastra은 gostino, 1952), including the present case, there had든. been surgical intervention. In their case, MacMahon and Urista (1964) were able to demonstrate in $\Omega$ vasion of the vascular sinuses of the dura. Otheres authors (Sherbaniuk and Shnitka, 1956; Perry, 1957)considered the role of radiotherapy as a causative factor in the secondary growth, perhaps merely by $\vec{\omega}$ prolonging survival.

As with other metastasizing tumours, the lungs. are a common site of secondary involvement; lungin metastases were found in 13 of the 20 cases (tables $\mathrm{I}_{\vec{N}}$ and II). Pleural deposits, as in the present case, were only slightly less frequently described (12 out of 20). ్ㅡ Local infiltration of the skull or vertebral bones waso noted in four of the cases, but in three (Perry, 1957; Fragoyannis and Yalcin, 1966), including the present case, there was involvement of long bones. There has been some discussion of the route of dissemination of the tumour cells. Direct invasion of the intracran-o ial venous channels was demonstrated by several authors (Sherbaniuk and Shnitka, 1956; Perrig, $\vec{\oplus}$ 1958; MacMahon and Urista, 1964), and diret extension of tumour along pelvic veins and t南e inferior vena cava was found in four of the inted spinal lesions (Weiss, 1955; Sharma, 1956; Patterson et al, 1961 ; Rubinstein and Logan, 1970). Judging by the overall pattern of metastases there seems little reason to doubt the view put forward by Frago- $\Rightarrow$ yannis and Yalcin, 1966) that spread can occur both윽 by lymphatic and blood vessel pathways.

As can be seen from table I, 12 of the 15 patients with intracranial tumours survived for two years or less. In contrast, all five patients with intraspinalo tumours had a much longer survival (table II). Clearly the local effects of tumour growth at this-. site are much less likely to shorten life but it iso possible that the greatly improved care and consequent prolongation of life of paraplegics in recent윽 years may be a factor contributing to remote metas- $\rightarrow$ tases. The patient described here survived 17 years after his second biopsy. Although there can be non absolute proof it is likely that this tumour was a recurrence of the lesion which was first biopsied 0 in 1940, giving a total survival of 32 years. N

The authors wish to thank Professor Sir Theo Crawford and Professor W. B. Robertson of the? Department of Pathology, St George's Hospitalo Medical School, for their helpful criticism in the preparation of the manuscript. 


\section{References}

Anderson, M. S. (1966). Myxopapillary ependymomas presenting in the soft tissue over the sacrococcygeal region. Cancer (Philad.), 19, 585-590.

Breslich, P. J. (1957). Ependymoma of the right occipital lobe with death from extracranial metastases. J. Lancet, 77, 99-103.

Feigin, I., and Volk, B. W. (1951). Malignant ependymoma infiltrating the scalp. Arch. Path., 51, 466-471.

Fragoyannis, S., and Yalcin, S. (1966). Ependymomas with distant metastases: report of two cases and review of the literature. Cancer (Philad.), 19, 246-256.

Glasauer, F. E., and Yuan, R. H. P. (1963). Intracranial tumors with extracranial metastases. J. Neurosurg., 20, 474-493.

Heath, M. H. (1963). Presacral ependymoma: case report and review of the literature. Amer. J. clin. Path., 39, 161-166.

Hesselvik, M., and Tygstrup, J. (1965). Metastasizing cerebral ependymoma. Report of a case in a child. Acta neuropath (Berl.), 4 , 416-420.

Højgaard, K., and Johansen, A. (1970). A case of ependymoma with remote metastasis. Acta path. microbiol. scand., Suppl., 212, 198-200.

Kernohan, J. W., and Fletcher-Kernohan, E. M. (1935). Ependymomas: a study of 109 cases. Res. publ. Ass. nerv. ment. Dis., 16, 182-209.

Kernohan, J. W., and Sayre, G. P. (1952). Tumors of the Central Nervous System (Atlas of Tumor Pathology, Sect. 10, fasc. 35), pp 43-59.' Armed Forces Institute of Pathology, Washington, D.C.

Maass, L. (1954). Occipital ependymoma with extracranial metastases. $J$. Neurosurg., 11, 413-421.

MacMahon, H. E., and Urista, M. S. (1964). The spread of an ependymoma from the brain to the lungs. Amer.J. Surg., 107 765-768.

Mastragostino, S. (1952). Entita e limiti del Problema delle Metastasi da Tumori Endocranici. Riv. Pat. nerv. ment., 73, 267-309.

Patterson, R. H., Jr., Campbell, W. G., Jr., and Parsons, H. (1961). Ependymoma of the cauda equina with multiple visceral met- astases. J. Neurosurg., 18, 145-150.

Perrin, E. V. (1958). Extracranial metastases from intracranial gliomata. Report of two cases in children. Amer. J. clin. Path., 30, 244-151.

Perry, R. E., Jr. (1957). Extracranial metastases in a case of intracranial ependymoma. Arch. Path., 64, 337-341.

Poser, C. M. (1956). The Relationship Between Syringomyelia and Neoplasm. Thomas, Springfield, III.

Robinson, E. F., and Sharkey, P. C. (1967). Primary intracranial neoplasms with extracranial metastases. Sth. med. J. (Bgham., Ala.), 60, 273-279.

Rubinstein, L., and Logan, W. J. (1970). Extraneural metastasis in ependymoma of the cauda equina. J. Neurol. Neurosurg. Psychiat., 33, 763-770.

Russell, D. S., and Rubinstein, L. J. (1971). Pathology of Tumours of the Nervous System, 3rd ed., pp. 154-163. Arnold, London.

Sharma, K. D. (1956). A metastasizing ependymoma of the cauda equina. Ind. J. med. Sci., 10, 639-641.

Sherbaniuk, R. W., and Shnitka, T. K. (1956). Metastasizing intracranial ependymoma. Amer. J. Path., 32, 53-65.

Svien, H. J., Mabon, R. F., Kernohan, J. W., and Craig, W. McK. (1953).'Ependymoma of the brain: pathologic aspects. Neurology (Minneap.), 3, 1-15.

Tenekoon, G. E. (1968). Subcutaneous myxo-papillary ependymoma of the sacrococcygeal region. Ceylon med. J., 13, 208-209.

Weiss, L. (1955). A metastasizing ependymoma of the cauda equina. Cancer (Philad.), 8, 161-171.

Wen, H. L., and Barrows, L. J. (1957). Ependymoma with extracranial metastases. (Abstr.) J. Neuropath. exp. Neurol., 16, 112.

Wentworth, P., and Birdsell, D. C. (1966). Intracranial ependymoma with extracranial metastases. J. Neurosurg., 25, 648-651.

Zimmerman, H. M. (1955). The nature of gliomas as revealed by animal experimentation. Amer. J. Path., 31, 1-29.

Zimmerman, H. M. (1957). The natural history of intracranial neoplasms with special reference to the gliomas. Amer. J. Surg., 93, 913-924. 